\title{
NILAI FILOSOFIS DAN TATA CARA PEMBANGUNAN "PELINGGIH GEDONG SAREN"
}

\author{
Ir. I Nyoman Gde Suardana, MT \\ Prodi Arsitektur Fakultas Teknik Universitas Dwijendra \\ E-mail: suar_bali@yahoo.com \\ I Wayan Aryawan, S.Si., M.Pd. \\ Prodi Pendidikan Bahasa Indonesia dan Daerah FKIP Universitas Dwijendra \\ E-mail: aryawan@undwi.ac.id \\ Desak Made Sukma Widiyani, ST., MT. \\ Prodi Arsitektur Fakultas Teknik Universitas Dwijendra \\ E-mail: sukmawidiyani@gmail.com
}

\begin{abstract}
Abstrak
Konsep Bangunan Bali hingga saat ini masih menjadi sebuah daya tarik tidak saja bagi para wisatawan namun juga berbagai peneliti yang ingin mendalami makna maupun fungsi dari bangunan tersebut. Tidak dapat dipungkiri bahwa keindahan bangunan Bali adalah salah satu faktor pembentuk keindahan alam Bali termasuk suasana religius didalamnya. Rumah sebagai bangunan yang paling dominan di sebuah areal pemukiman, juga memiliki ciri khas tersendiri di Bali. Rumah Bali bisa dipastikan memiliki tempat/sarana pemujaan yang biasa disebut Sanggah/Merajan. Bahkan menurut konsep Hindu, Sanggah/Merajan adalah bangunan terpenting dalam sebuah rumah/tempat tinggal.
\end{abstract}

Pelinggih Gedong Saren merupakan salah satu bagian dari Sanggah/Merajan. Bangunan ini adalah warisan leluhur yang perlu dikembangkan dan dilestarikan. Sampai saat ini, naskah yang membicarakan tentang Pelinggih Gedong Saren secara khusus terbilang cukup langka. Sehingga sangat perlu untuk melakukan studi khusus tentang Pelinggih Gedong Saren agar nantinya bisa dipakai sebagai bahan pertimbangan di dalam perencanaan atau pembuatan Pelinggih Gedong Saren didalam suatu Merajan atau Sanggah. Masih banyaknya rahasia dan keunikan pada Pelinggih Gedong Saren, yang notabena adalah bangunan penting dalam tempat suci keluarga umat Hindu.

Penelitian ini merupakan penelitian deskriptif (descriptive reasearch), yang dimaksudkan untuk eksplorasi dan klarifikasi mengenai suatu fenomena atua kenyataan sosial, dengan jalan mendeskripsikan sejumlah variabel yang berkenaan dengan masalah dan unit yang diteliti. Jenis penelitian ini tidak dimaksudkan untuk menarik generasi yang menyebabkan sesuatu gejala atau kenyataan sosial. Oleh karena itu, penelitian ini tidak menggunakan dan tidak melakukan pengujian hipotesis karena tidak dimaksudkan untuk membangun dan mengembangkan perbendaharaan teori.

Penelitian ini menggunakan dua jenis data yaitu primer dan skunder. Data primer diperoleh dari hasil penelitian ke objek (lapangan) yang diperoleh secara langsung melalui wawancara/interview dan juga observasi. Sedangkan data skunder diperoleh dari studi literature, kepustakaan dan lontar-lontar yang terkait dengan penelitian ini. Selanjutnya, analisa dilakukan dengan metode analisis deskriptif yaitu sebuah teknik yang berusaha menguraikan dan menjabarkan sebuah permasalahan (variable penelitian) menjadi analisa yang mampu menjelaskan setiap permasalahan (variable penelitian) tersebut secara jelas.

Kedepan, pembangunan pariwisata akan sangat bergantung dari Roh Pariwisata itu sendiri. Bagi Bali yang dikenal sebagai destinasi terbaik dunia, budaya, adat istiadat, serta keunikan Bali yang bernafaskan Hindu adalah roh dari pariwisata itu sendiri. Memahami makna setiap bangunan yang merupakan penunjang keindahan dan memiliki fungsi penting dalam kehidupan religius masyarakat adalah tujuan jangka panjang dari penelitian ini.

Kata Kunci: nilai filosofis, pembangunan, gedong saren 


\section{Abstract}

The concept of Bali Building is still a tourist attraction not only for tourists but also various researchers who want to explore the meaning and function of the building. It can not be denied that the beauty of Balinese buildings is one of the factors that make up the natural beauty of Bali including the religious atmosphere in it. The house as the most dominant building in a residential area, also has its own characteristics in Bali. Rumah Bali can certainly have a place / means of worship commonly called Sanggah / Merajan. Even according to the Hindu concept, Sanggah / Merajan is the most important building in a house / residence.

Pelinggih Gedong Saren is one part of Sanggah / Merajan. This building is an ancestral heritage that needs to be developed and preserved. Until now, the manuscripts that talk about Pelinggih Gedong Saren in particular are quite rare. So it is very necessary to conduct a special study on Pelinggih Gedong Saren so that later can be used as a consideration in the planning or making Pelinggih Gedong Saren in a Merajan or Sanggah. There are still many secrets and uniqueness in Pelinggih Gedong Saren, which notabena is an important building in the holy place of Hindu family.

This research is a descriptive reasearch, which is intended for exploration and clarification of a phenomenon or social reality, by describing a number of variables concerning the problem and the unit under investigation. This type of research is not intended to attract a generation that causes a symptom or a social reality. Therefore, this study does not use and do not perform hypothesis testing because it is not intended to build and develop theory treasury.

This study uses two types of data, namely primary and secondary. Primary data obtained from the results of research into the object (field) obtained directly through interview / interview and also observation. While the secondary data obtained from the study of literature, literature and lontar associated with this research. Furthermore, the analysis is done by descriptive analysis method that is a technique that try to describe and describe a problem (research variable) to be an analysis that able to explain each problem (research variable) is clear.

In the future, the development of tourism will depend on the Spirit of Tourism itself. For Bali, known as the world's best destination, culture, customs, as well as the uniqueness of Bali that breathes Hinduism is the spirit of tourism itself. Understanding the meaning of each building that is a supporter of beauty and has an important function in the religious life of society is the long-term goal of this research.

Keywords: philosophical values, development, gedong saren.

\section{I.Pendahuluan}

Studi tentang Pelinggih Gedong Saren ini dilakukan guna memahami lebih mendalam lagi sebagian dari ilmu pengetahuan arsitektur tradisional Bali yang mendekati kebenaran, sehingga arah pengembangan nilai luhur yang tinggi dari warisan nenek moyang kita menjadi kukuh dan kuat, dan juga dapat diungkapkan untuk menambah perbendaharaan kebudayaan bangsa sebagai suatu bahan informasi dan gambaran yang menyeluruh bagi masyarakat Bali khususnya dan bangsa Indonesia pada umumnya.

\subsection{Latar Belakang Penelitian}

Adanya beberapa faktor atau permasalahan yang muncul dan perlu mendapatkan pemecahan yaitu:

Karena langkanya naskah yang membicarakan tentang Pelinggih Gedong Saren secara khusus, maka perlu adanya studi khusus tentang Pelinggih Gedong Saren yang nantinya bisa dipakai sebagai bahan pertimbangan di dalam perencanaan atau pembuatan Pelinggih Gedong Saren didalam suatu merajan atau sanggah. 
Karena masih banyak rahasia dan keunikan yang ada pada Pelinggih Gedong Saren, sehingga perlu adanya suatu penelitian yang khusus tentang nilai-nilai filosofis yang terkandung didalamnya.

Karena merupakan salah satu jenis bangunan suci bagi masyarakat Hindu khususnya di Bali sebagai warisan leluhur yang perlu dikembangkan dan dilestarikan, sehingga kita perlu mengetahui latar belakang didirikannya Pelinggih Gedong Saren dan sekaligus bisa diketahui nilai-nilai sejarah dan budaya yang terkandung didalamnya.

Bertitik tolak dari masyarakat bali, dimana Pelinggih Gedong Saren sebagai bagian dari arsitektur tradisional Bali, merupakan produk kebudayaan yang diwariskan secara turun temurun oleh leluhur kita yang merupakan pancaran agama Hindu yang melandasi kepercayaan, adat istiadat sebagai norma-norma kehidupan. Sehingga perlu adanya usaha untuk melestarikannya agar nilai-nilai budaya yang terdapat di dalamnya tidak menjadi luntur.

\subsection{Rumusan Masalah}

Berdasarkan uraian latar belakang di atas, maka dapat dirumuskan masalah sebagai berikut:

a. Bagaimana proses pembangunan Pelinggih Gedong Saren, dilihat dari tata letak, pemakaian bahan, ukuran-ukuran dan tata upacara menurut aturan Arsitektur Tradisional Bali.

b. Bagaimana menemukan keunikan-keunikan yang ada pada Pelinggih Gedong Saren sekaligus mengetahui nilai filosofis yang terkandung didalamnya

c. Bagaimana mengungkap nilai-nilai sejarah yang ada pada Pelinggih Gedong Saren, dan mengetahui latar belakang didirikannya Pelinggih Gedong Saren.

\subsection{Tujuan dan Sasaran Penulisan}

\section{Tujuan}

\section{a. Tujuan Khusus}

(1) Mendapatkan suatu bentuk pedoman yang diambil dari beberapa sumber mengenai Pelinggih Gedong Saren yang nantinya bisa dipakai acuan didalam merancang atau mendirikan Pelinggih Gedong Saren.

(2) Merencanakan suatu Pelinggih Gedong Saren yang menggunakan ornamenornamen atau keunikan-keunikan sebagai ciri khas Pelinggih Gedong Saren yang sesuai dengan teori-teori yang sudah didapatkan.

(3) Mengetahui latar belakang adanya Pelinggih Gedong Saren yang sangat kental dengan nilai-nilai sejarahnya, sehingga dapat diwariskan dan dilestarikan kepada generasi selanjutnya.

\section{b. Tujuan Umum}

(1) Mahasiswa sebagai calon intelektual diharapkan mengetahui serta mampu mengamalkan tentang tata cara proses pembangunan Arsitektur Tradisional Bali 
(2) Mahasiswa diharapkan dapat memahami, menerapkan, dan mengamalkan bahwa setiap aspek kehidupan masyarakat bali telah dijiwai oleh agama Hindu termasuk Arsitektur Tradisional Bali.

(3) Untuk melestarikan warisan budaya dan mengembangkan nilai-nilai religius yang terkandung didalamnya.

\section{Sasaran}

a. Memahami dan menguraikan fungsi, filosofi, bentuk dan tata letak dari Pelinggih Gedong Saren.

b. Mengetahui makna dan fungsi dari keberadaan Pelinggih Gedong Saren dalam suatu tempat suci, Pura ataupun Merajan

c. Mengetahui arti dari adanya patung Dewa pada Pelinggih Gedong Saren

\subsection{Batasan Penelitian}

Meneliti tetang sejauh mana peningkatan, dan pengembangan kualitas dari perencanaan suatu Pelinggih Gedong Saren yang sesuai dengan teori-teori , literatur, informasiinformasi dan dari studi banding dengan kenyataan di lapangan.

Meneliti Pelinggih Gedong Saren dilihat dari aspek :

(a) Aspek perencanaan

(b) Aspek desain bangunan

(c) Aspek Struktur dan Konstruksi

(d) Aspek ritual atau upacara yang nantinya akan menghasilkan disain fisik yang berupa gambar-gambar pra-rencana dan maket.

\section{Metode Penelitian}

\subsection{Pengumpulan Data}

Dalam pengumpulan data-data yang dapat mendukung penulisan ini, menggunakan beberapa teknik yaitu

a. Studi Literatur yaitu dengan memilih data-data literatur yang ada kaitannya dengan permasalahan yang ada

b. Observasi yaitu dengan cara mengadakan pengamatan langsung ke lapangan dengan mengambil 3 sample/kasus yang nantinya dapat dipakai perbandingan di dalam penulisan

c. Wawancara yaitu dengan melakukan wawacara langsung dengan orang yang berkompeten dan dapat dipercaya dalam permasalahan ini seperti Pedanda, Undagi, Tukang Banten dll

\subsection{Analisis Data}

a. Lontar (Asta kosali, Asta Bumi, dll). 
b. Nara sumber (Sulinggih, Undagi, Sangging, dll).

c. Studi Kasus (minimal 3 kasus proyek).

d. Penentuan bentuk, dimensi, bahan, proses pendirian.

\section{HASIL DAN PEMBAHASAN}

\subsection{Tempat Suci / Parhyangan Tradisional Bali}

Umat Hindu khususnya di Bali memiliki bermacam-macam jenis parhyangan atau tempat suci, yang berfungsi sebagai stana dari roh leluhur, betara, para dewa-dewi, dan juga sebagai stana dari Ida Sanghyang Widi Wasa. Bangunan suci atau tempat suci tradisional Bali dapat kita jumpai hampir disetiap wilayah yang ada di Bali, baik di perkotaan maupun di pedesaan, di gunung, di pinggir pantai, di persawahan, di kuburan dan dibeberapa tempat lainnya, sehingga pulau Bali juga mendapat julukan pulau seribu pura.

\subsection{Jenis-jenis tempat suci / Parhyangan}

Tempat suci umat hindu yang ada di Bali dapat kita klasifikasikan menjadi 4 (empat) jenis yaitu:

a. Pura Kahyangan Jagat

b. Pura Kahyangan Tiga / Tri Kahyangan

c. Pura Kahyangan Swagina

d. Kahyangan Keluarga

Berikut ini merupakan jenis-jenis tempat suci atau Kahyangan beserta contohnya:

a. Pura Kahyangan Jagat, yang di sungsung oleh seleruh umat Hindu tanpa membedakan status, soroh ataupun wangsa, yaitu:Pura Besakih, Pura Batur, Pura Lempuyang Luhur, Pura Andakasa, Pura Batukaru, Pura puncak mangu, Pura Gua Lawah, Pura Uluwatu, Pura Puserin jagat dan Puser Tasik, Pura Rambut Siwi, Pura Tirta Empul, Pura Kehen, Pura Samuan Tiga, Pura Sakenan, Pura Peti Tenget, Pura Melanting Pulaki, Pura Ponjok Batu, Pura kedaton di Kukuh Tabanan, Pura Batur Penulisan di Bangli, Pura Temu Waras di Tabanan, Pura Jagatnatha, Pura Puncak Padang Dawa di Tabanan dan masih banyak lagi pura-pura yang lainnya

b. Pura Kahyangan Tiga / Tri Kahyangan, yang terletak di setiap Desa Pekraman dan di sungsung oleh penduduk desa setempat. Diantaranya; (1) Pura Desa \& Bale Agung - sebagai pemujaan Dewa Brahma; (2) Pura Puseh - sebagai pemujaan Dewa Wisnu; (3) Pura Dalem - sebagai pemujaan Dewa siwa

c. Pura Kahyangan Swagina, pura yang dipuja menurut keahlian / profesi / geginan seseorang, diantaranya;

(1) Pura Melanting, yang terletak di pasar, yang disungsung oleh para pedagang yang berjualan di pasar tersebut

(2) Pura Subak Ulun Swi, yang disungsung oleh beberapa kelompok Subak

(3) Pura Ulun Empelan, yang disungsung oleh satu kelompok subak yang menggunakan air dari empelan tersebut 
(4) Pura Ulun Carik, disungsung oleh salah seorang petani anggota subak yang memiliki sepetak atau beberapa petak sawah

(5) Pelinggih Taksu yang terdapat pada sanggah atau di natar rumah, disungsung oleh keluarga yang memiliki profesi sebagai Undagi, Pregina, Pande besi dan lain-lainnya.

d. Kahyangan keluarga / Paibon,

(1) Merajan Alit (Tri Lingga / 3 pelinggih), disungsung oleh 1 sampai dengan 20 keluarga

(2) Merajan Madia ( Panca Lingga / 5 pelinggih, Sapta Lingga / 7 pelingih ) disungsung oleh 21-40 keluarga

(3) Merajan Agung / Paibon ( Eka Dasa Lingga / 11 pelinggih ), disungsung oleh 41 sampai dengan 100 lebih keluarga (Anom, Ida Bagus, hal 1)

\subsection{Dasar- Dasar / Landasan Filosofis}

Adanya berbagai macam tempat suci yang ada di Bali ini sesuai dengan konsep Tri Hita Karana yang diyakini oleh masyarakat Hindu di Bali. Konsep Tri Hita Karana ini merupakan konsep kehidupan dari masyarakat Bali didalam menjalani kehidupan seharihari untuk mencapai kehidupan yang selaras, serasi dan seimbang kepada semua makhluk yang hidup di dunia. Konsep Tri Hita Karana adalah

a. hubungan manusia dengan Tuhan

b. hubungan manusia dengan manusia yang lainnya

c. hubungan manusia dengan alam

Dengan menjalankan 3 konsep kehidupan ini, masyarakat Hindu di Bali percaya bahwa kehidupan akan menjadi lebih baik. Secara langsung pada penerapanya masyarakat bali mencoba menterjemahkan konsep Tri Hita Karana ini kedalam berbagai aspek kehidupan diantaranya di dalam suatu wilayah desa mempunyai 3 unsur pokok diantaranya ;

a. Parhyangan sebagai hubungan manusia dengan Tuhan, maka dalam satu desa memiliki Tri kahyangan yaitu Pura Desa, Pura Puseh dan Pura Dalem.

b. Pawongan sebagai hubungan manusia dengan manusia, didalam suatu desa terdapat kawasan permukiman penduduk.

c. Palemahan sebagai hubungan manusia dengan alam lingkungan, didalam satu desa memiliki satu kawasan persawahan dan kuburan (konsep agama Hindu di Bali ; babadbali.com ).

Dari konsep Tri Hita karana akan lahir lagi konsep Tri angga dan Tri Mandala. Tri Angga dan Tri Mandala merupakan suatu acuan di dalam membangun suatu bangunan tradisional Bali. Bagian-bagian dari Tri Angga: a) Kepala; b) Badan; c) Kaki Bagian-bagian dari tri Mandala : a) Utama ; b) Madya; c) Nista

Didalam satu pekarangan perumahan tradisional Bali juga memakai ketiga konsep tersebut diatas yaitu, didalam satu pekarangan harus memiliki 
a. Merajan / Sanggah sebagai tempat untuk sembahyang, yang merupakan hubungan manusia dengan Tuhan (Parhyangan)

b. bangunan Bale untuk tempat tidur dan kegiatan sehari-hari, sebagai hubungan manusia dengan manusia (Pawongan)

c. teben / tempat pemeliharaan ternak, sebagai hubungan manusia dengan alam (Palemahan)

\subsection{Tinjauan Sanggah / Pemerajan}

Sanggah / merajan adalah wajib dimiliki oleh setiap keluarga Hindu yang berasal dari Bali, karena mendirikan merajan / sanggah merupakan salah satu fakor diantara tiga fakor yang terdapat pada konsep Tri Hita Karana yang diyakini oleh masyarakat Hindu Bali. Sanggah / Merajan merupakan tempat suci yang ada dalam satu pekarangan rumah, yang berfungsi untuk menyembah Tuhan, Dewa-dewi, dan juga roh-roh suci leluhur.

\subsection{Sejarah Singkat Asal Mula Dibangunnya Sanggah atau Merajan}

Sanggah atau pemerajan baru dikenal oleh masyarakat Bali setelah agama Hindu masuk ke Bali. Tetapi sebelum agama Hindu masuk ke Bali, orang Bali sudah melakukan penyembahan terhadap roh leluhur pada tahun 2500 sebelum masehi pada jaman batu dan pada 500 tahun sebelum masehi pada jaman perunggu. Pada waktu itu yang dianggap sebagai pelinggih adalah tumpukan-tumpukan batu seperti candi, menhir, sarcophagus yaitu peti mayat yang terbuat dari batu yang ditemukan di desa sembiran, tengenan, gelgel, dan lain-lain. (Sutaba, I Made, hal 31)

Kemudian setelah agama Hindu masuk ke Bali yang pertama di sebarkan oleh Resi Markandya, Empu Sidi Mantra dan di teruskan oleh empat keturunannya yaitu Empu Gnijaya, maka tempat pemujaan leluhur dibuatkan sanggah atau merajan di setiap pekarangan rumah penduduk.

Pada waktu raja Erlangga memerintah di Jawa, di Bali terdapat 9 aliran/ sekte kepercayaan. 9 (Sembilan) aliran / sekte terdiri atas: aliran / sekte Siwa Sidhanta; aliran / sekte Pasupata; aliran / sekte Bhairawa; aliran / sekte Waisnawa; aliran / sekte Bodha (Sogata); aliran / sekte Brahma; aliran / sekte Resi; aliran / sekte Sore; aliran / sekte Ganapatya (Bandesa K. Tonjaya, I Nym Gd, hal : 23 ).

Kemudian untuk menyatukan ke-sembilan aliran itu, maka raja Erlangga mengutus Empu Kuturan ke Bali. Setelah sampai di Bali beliau melakukan perubahan-perubahan, menyatukan sembilan aliran tersebut menjadi satu paham Tri Murti yaitu memuja dewa Brahma, Wisnu, dan Siwa. Dan sebagai tempat pemujaannya di masing-masing desa pekraman yang ada di bali dibangunlah Pura Kahyangan Tiga, yaitu:

(1) Pura Desa sebagai tempat pemujaan Dewa Brahma tampatnya di sebelah utara desa

(2) Pura Puseh sebagai tempat pemujaan Dewa Wisnu tempatnya di tengahtengah desa 
(3) Pura Dalem sebagai tempat pemujaan Dewa Siwa tempatnya di Selatan dekat dengan kuburan.

Sedangkan pada tingkat keluarga, di pemerajannya untuk pemujaan dewa Tri Murti dibuatkan pelinggih Kemulan. Pelinggih Kemulan ini memiliki 3 rong yang masing masing rongnya memiliki fungsi yang berbeda. Rong yang berada di sebelah kanan berfungsi untuk stana Dewa Brahma, rong di sebelah kiri berfungsi sebagai stana Dewa Wisnu, dan yang di tengah-tengah berfungsi sebagai stana Dewa Siwa.

Setelah Empu Kuturan, ada lagi seorang maha resi yang datang ke Bali pada tahun 1489 yang bernama Danghyang Dwijendra atau juga dikenal dengan sebutan Bhatara Sakti Bawu Rawuh. Beliau menyempurnakan lagi dari apa yang telah diajarkan oleh Empu Kuturan yaitu selain mendirikan Tri Kahyangan dan Sanggah Kemulan beliau juga menganjurkan agar dibuatkan sebuah Padmasana sebagai tempat pemujaan Sanghyang Tunggal atau Sanghyang Widhi Wasa.

\subsection{Tata Letak Sanggah / Pemerajan}

Dalam arsitektur tradisional Bali, penataan atau penzoningan suatu posisi bangunan disesuaikan dengan fungsi bangunan itu sendiri. Untuk mengatur tentang tata letak bangunan maka dalam arsitektur tradisional Bali terdapat pola Tri mandala yaitu satu pekarangan yang didalam penataan zoningnya dibagi 3 bagian diantaranya:

(1) utama mandala, di sebelah utara

(2) madya mandala, di tengah

(3) nista mandala, di sebelah selatan

Dari pola Tri Mandala akan terlahir lagi suatu pola penataan posisi bangunan yang bernama Sanga Mandala yaitu satu pekarangan yang didalam zoningnya di bagi 9 (Sembilan). Oleh karena sanggah / pemerajan merupakan tempat suci sebagai hubungan manusia dengan Tuhan, sehingga sanggah / pemerajan mempunyai nilai fungsi yang paling tinggi dibandingkan dengan bangunan-bangunan yang lain, maka didalam penempatannya dalam suatu pekarangan rumah juga harus menempati mandala yang memiliki nilai paling tinggi yaitu utama mandala yang ada pada Tri Mandala sedangkan pada konsep sanga mandala yaitu pada Utamaning utama mandala yaitu di daerah timur laut (kaja kangin).

\subsection{Jenis atau Tingkatan Sanggah / Pemerajan}

Kalau kita perhatikan beberapa sanggah-sanggah yang kita lihat di beberapa tempat, pasti kita akan menjumpai beberapa perbedaan khususnya pada banyaknya pelinggih yang ada dalam satu sanggah dengan sanggah yang lain. Hal ini karena sanggah / pemerajan mempunyai beberapa tingkatan, dimana masing masing tingkatan dibedakan oleh jumlah pelinggih yang ada di dalam suatu sanggah tersebut.

Jenis atau tingkatan sanggah dapat dibedakan menjadi empat tingkatan yaitu:

(1) sanggah / pemerajan Tri Lingga, jumlah pelinggihnya adalah tiga buah

(2) sanggah / pemerajan Panca Lingga, jumlah pelinggihnya adalah lima buah 
(3) sanggah / pemerajan Sapta Lingga, jumlah pelinggihnya adalah tujuh buah

(4) sanggah / pemerajan Eka Dasa Lingga, jumlah pelinggihnya adalah sebelas buah dari keempat macam sanggah tersebut masyarakat Hindu Bali dapat memilih salah satu diantara keempat pilihan tersebut, yang disesuaikan dengan kemampuan dan luasnya areal sanggah.

\subsection{Pelinggih-pelinggih yang Ada di Sanggah / Pemerajan}

Seperti yang sudah diaungkapkan diatas bahwa merajan memiliki perbedaan-perbedaan pada jumlah pelinggihnya sesuai dengan jenis merajannya. Tetapi walaupun demikian di dalam suatu merajan harus mempunyai satu pelinggih pokok yang harus ada didalam membangun suatu merajan, baik merajan Tri Lingga, Panca Lingga, Sapta Lingga, maupun merajan Eka Dasa Lingga. Pelinggih pokok yang dimaksud adalah Pelinggih Kemulan. Oleh karena itu Pelinggih Kemulan adalah pelinggih yang harus di bangun pertama kali, setelah itu kalau punya kemampuan boleh ditambahkan dengan pelinggihpelinggih yang lain seperti Pelinggih Taksu, Pelinggih Ratu Ngurah dan lain-lain disesuaikan dengan kemampuan dan tempatnya.

Pelinggih Gedong Saren pada umumnya hanya dapat kita jumpai pada merajan / sanggah gede saja. seperti uraian diatas mengenai nama-nama pelinggih di Pemerajan, kita mendapatkan nama Pelinggih Gedong Saren hanya terdapat pada merajan Sapta Lingga, dan Eka Dasa Lingga. Hal ini karena Pelinggih Gedong Saren bukan merupakan pelinggih pokok dalam suatu merajan, melainkan hanya sebagai pelinggih tambahan.

\subsection{Filosofis Pelinggih Gedong Saren}

Dibangunnya Pelinggih Gedong Saren merupakan salah satu wujud suatu rasa penghargaan dan bakti kita kepada orang-orang suci, yang terdapat dalam salah satu ajaran Tri Rna. Tri Rna adalah tiga jenis hutang yang harus kita bayar semasa hidup kita. Ketiga hutang tersebut adalah

a. Dewa Rna adalah hutang kita kepada Ida Sanghyang Widhi Wasa, yang dapat kita bayar dengan melaksanakan upacara Dewa Yadnya dan dengan sujud bakti kepada Tuhan.

b. Pitra Rna adalah hutang kita kepada para Pitara atau kepada leluhur kita, yang dapat kita bayarkan dengan melaksanakan upacara Pitra Yadnya, dan juga Bakti kepada Leluhur

c. Resi Rna adalah hutang kita kepada para orang-orang suci, yang dapat dibayarkan dengan melaksanakan upacara Resi Yadnya.

Ida Betara Rambut Sedana sangat dipuja oleh masyarakat Bali, maka dari itu sesuai dengan ajaran Dewa Rna yaitu hutang kita kepada Ida Sang Hyang Widhi Wasa, maka masyarakat Bali sangat menghormati Beliau dengan cara disetiap pemerajan atau sanggah gede dibuatkan satu pelinggih untuk memuja Ida Betara Rambut Sedana, yang bernama Pelinggih Gedong Saren.

\subsection{Fungsi Pelinggih Tata Letak Pelinggih Gedong Saren}

Dari ke tiga sumber yang diperoleh, maka dapat disimpulkan bahwa Pelinggih Gedong Saren posisinya di sebelah timur menghadap ke barat berjejer dengan pelinggih-pelinggih 
yang ada di timur. Namun sesuai dengan kenyataan dilapangan, di daerah Denpasar banyak kita mendapati posisi Pelinggih Gedong Saren berada di depan sisi sebelah kiri dari Pelinggih Pertiwi. Hal ini dikarenakan pelinggih tersebut bukan merupakan pelinggih untuk pemujaan Ida Betara Rambut Sedana, melainkan sebagai tempat untuk meletakkan prasarana upacara seperti Pretima, Tigasan dan lain sebagainya. Namun walaupun demikian pelinggih ini juga bisa difungsikan untuk pemujaan Ida Betara Hyang Guru atau roh leluhur.

\subsection{Bentuk dan Palih Pelinggih Gedong Saren}

Seperti halnya bentuk-bentuk pelinggih yang lain, Pelinggih Gedong Saren juga memakai konsep Triangga yaitu memiliki tiga bagian atau tiga palih diantaranya :

a. Bagian kaki disebut dengan palih Bebaturan Sor / Pertiwi yaitu, bebaturan yang terletak paling bawah, terbuat dari pasangan batu.

b. Bagian badan disebut dengan palih Batur Sari yaitu, bagian bebaturan yang terletak di atas bebaturan sor, yang langsung menopang Rongan.

c. Bagian kepala disebut dengan palih sari atau Rongan yaitu, bagian paling atas dari pelinggih tepatnya diatas Batur Sari sampai pada atap pelinggih.

Kalau dilihat dari bentuk denahnya adalah berbentuk segi empat panjang, hal ini terlihat pada bagian atapnya memakai dedeleg.

\subsection{Penggunaan Bahan Bangunan}

Penggunaan bahan bangunan pada Pelinggih Gedong Saren disini dapat diuraikan menjadi beberapa bagian diantaranya:

a. Bagian bebaturan memakai bahan batu-batuan yang memiliki warna Tri Datu yaitu merah, putih, dan hitam. Jenis-jenis bahan yang memiliki warna Tri Datu adalah

(1) Batu bata yang memiliki warna merah

(2) Batu padas yang memiliki warna putih

(3) Batu candi / lahar yang memiliki warna hitam

b. Bagian rongan, memakai bahan dari kayu.

Menurut arsitektur tradisional Bali, jenis kayu yang dipakai untuk parhyangan tidak boleh sama dengan jenis kayu yang dipakai untuk bangunan pawongan. Jenis kayu yang boleh dipakai pada parhyangan adalah: 1) Prabu: cenana; 2) Patih: menengen, 3) Arya: cempake, 4) Demung: majegau, 5)Tumenggung : suren.

Kayu nangka walaupun tidak memiliki kelas untuk parhyangan, namun kayu nangka merupakan prabu pada jenis kayu untuk pawongan, maka kayu nangka juga boleh dipakai untuk parhyangan.

c. Bagian atap, memakai bahan dari alang-alang dan dari ijuk.

Untuk bahan atap, alang-alang merupakan bahan atap yang paling utama karena alang-alang menurut cerita dan menurut kepercayaan masyarakat Hindu merupakan 
tumbuhan yang mendapatkan percikan tirta kamandalu pada saat perebutan tirta kamandalu antara para dewata dengan para raksasa.

\subsection{Sistem Struktur}

Sistem sturktur yang di pakai dalam pembuatan Pelinggih Gedong Saren terdapat dua jenis sistem struktur yaitu:

a. Sistem struktur rangka:

Sistem struktur rangka ini dipakai pada bagian kepala atau rongannya sampai pada atapnya, dimana pada bagian rongan sampai pada atapnya ini dibuat dari konstruksi kayu.

b. Sistem struktur massa:

Sistem struktur massa ini dipakai pada bagian bebaturan mulai dari bebaturan sor/ pertiwi sampai pada batur sari, dimana pada bagian bebaturan ini di bagian pinggirnya menggunakan pasangan bata dan ditengahnya menggunakan penyegseg yang terbuat dari tanah.

\subsection{Tenaga yang dibutuhkan pada Tahap Pembangunan}

Di dalam pembangunan sebuah Pelinggih Gedong Saren diperlukan tenaga-tenaga ahli seperti: tenaga pengarah upacara, pelaksana fisik, dan penata hiasan. Adapun tenaga dalam pelaksanaan fisiknya adalah: tenaga perencana, tenaga ahli.

\section{a. Tenaga perencana}

Didalam arsitektur tradisional Bali, undagi merupakan tenaga perencana yang bisa merancang suatu bangunan yang sesuai dengan aturan-aturan arsitektur tradisional Bali. Dalam hal ini Pelinggih Gedong Saren merupakan suatu bangunan yang memakai aturanaturan arsitektur tradisional Bali, sehingga seorang undagi sangat diperlukan didalam proses perancangannya, mulai dari pembuatan gegulak sebagai satuan-satuan dimensi sampai pada pembuatan sukatnya.

\section{b. Tenaga ahli}

Tenaga ahli di dalam proses mulai dari persiapan sampai pada tahap penyelesaian sangat dibutuhkan, misalnya didalam menentukan dewasa ayu, merancang, membangun dan melaspas pelinggih. Undagi yang seniman dan yang telah berada dalam tingkatan empu merupakan tenaga ahli yang seutuhnya, yang dapat menentukan dewasa ayu, perancangan ragam hias, pelaksanaan dan sampai pada upacaranya.

Berikut merupakan tenaga ahli dalam bidangnya : 1) Ahli menentukan hari baik ( dewasa ayu ) disebut dengan ahli wariga; 2) Ahli yang menguasai weda-weda dalam pedoman pemujaan dan pedoman puja astawa dikuasai oleh sulinggih dan pemangku; 3) Ahli dalam pengerjaan banten disebut dengan tukang banten; 4) Undagi dalam pelaksanaan proses pembangunan dibantu oleh beberapa tukang ahli dalam bidang tertentu misalnya : tukang kayu, tukang mengatapi, tukang ukir, dan tenaga ahli lainnya; 5) Ahli dalam membuat ragam hiasan disebut dengan sangging

\subsection{Ragam Hias}


Dalam arsitektur tradisional Bali ragam hias sangat berperan penting didalam tampilan suatu bangunan, dimana ragam hias akan mempengaruhi nilai estetika bangunan tersebut, sehingga dengan pemilihan ragam hias yang tepat dan juga penempatannya yang sesuai akan bisa membuat bengunan tersebut lebih indah. Pada umumnya ragam hias yang dipakai didalam hiasan bangunan diambil dari bentuk-bentuk kehidupan di bumi seperti, manusia, binatang (fauna), dan tumbuh-tumbuhan (flora).

Pada Pelinggih Gedong Saren ragam hias yang digunakan pada umumnya tidak terlalu banyak karena media yang akan dihias juga tidak begitu luas sehingga pemilihan ragam hiasnya hanya beberapa macam saja misalnya: karang asti, simbar, karang goak, dan pecira.

\subsection{Proses Pembangunan dan Upacaranya}

Sebagaimana halnya proses pembangunan pada bangunan tradisional Bali pada umumnya, proses pembangunan Pelinggih Gedong Saren juga harus melalui proses dan upacara mulai dari persiapan sampai dengan penyelesaian.

\subsection{Proses Persiapan dan Upacaranya}

Dalam proses persiapan ada beberapa tahap yang harus di laksanakan yaitu:

a. Penentuan lokasi

Untuk mendirikan pelinggih harus ditentukan dulu dimana posisi pelinggih yang akan dibangun agar sesuai dengan ketentuan, jenis dan fungsi pelinggih yang dalam arsitektur tradisional Bali proses ini disebut dengan nyukat dengan disertai upacara terlebih dahulu.

b. Menentukan / membuat gegulak

Untuk menentukan gegulak, yang diambil adalah orang yang dituakan didalam suatu keluarga sebagai pangemong merajan / sanggah yang akan dibangun. Dalam pembuatan gegulak harus melalui upacara pembuatan gegulak terlebih dahulu

c. Pengadaan bahan

- Penggunaan bahan untuk dasar, bebaturan menggunakan batu alam yang diambil dari jenis batu alam yang ada pada daerah setempat

- Penggunaan bahan atap juga diambil dari bahan yang ada di daerah setempat seperti ijuk, dan alang-alang

- Kayu sebagai bahan konstruksi rangka rongan dipilih kayu yang baik untuk dipakai pada pelinggih atau parhyangan, dan didalam proses penebangannya juga sesuai dengan aturan arsitektur tradisional Bali yang disertai dengan upacara penebangan terlebih dahulu

d. Pengolahan bahan

Setelah bahan-bahan didapatkan, bahan-bahan seperti kayu dan batu alam tadi diolah atau dibentuk menjadi bahan-bahan setengah jadi.

\subsection{Teknik Pembuatan dan Upacaranya}

Setelah bahan-bahan siap, lalu pada tahap selanjutnya adalah tahap pengerjaan, yang dimulai dari penerjaan bagian bawah yaitu bebaturan sampai pada rongan dan atapnya.

a. Pengerjaan bagian bawah atau bebaturannya. 
Pada bagian ini terdapat tepas hujan, bebaturan dan undagi yang sudah diperhitungkan dimensinya pada saat perencanaan. Sebelum pemasangan tepas hujan dan bebaturannya terlebih dahulu ada beberapa tahap proses dan upacara yang dilaksanakan mulai dari

(1) proses dan upacara nyukat, yang bertujuan untuk menentukan posisi pelinggih yang akan dibangun, serta denah dimensi pelinggihnya

(2) proses dan upacara ngeruak, yang bertujuan membersihkan lahan yang akan dibangun dan sekaligus membuat lubang pondasi sesuai dengan sukat

(3) proses dan upacara nasarin, yaitu peletakan batu pertama pada bangunan yang menggunakan sarana upacara.

Setelah proses dan upacara nasarin selesai baru dilanjutkan dengan proses pengerjaan babaturannya

b. Pengerjaan bagian rongan

Pada bagian rongan ini merupakan pekerjaan konstruksi rangka kayu, dimulai dengan perakitan saka, sunduk, lambang, waton, slimar, pemade, pemucu, dan iga-iga.

c. Pengerjaan bagian penutup atap

Pekerjaan setelah perakitan rongan sampai ke rangka atap dilanjutkan dengan pemasangan penutup atap yaitu dengan memakai ijuk atau alang-alang.

Biasanya pada pengerjaan bagian rongan sampai pada penutup atap dikerjakan di bawah, dan setelah selesai sampai pada tahap finishing baru bagian rongan tersebut diangkat ke atas batur sari sebagai penumpu rongan.

\subsection{Tahap Penyelesaian dan Upacaranya}

Setelah pelinggih selesai secar keseluruhan, sebelum diupacarai, pelinggih tersebut terlebih dahulu dibersihkan secara fisik yang disebut dengan ngeresikin. Setelah pelinggih benar-benar bersih, baru dibuatkan upacara terakhir yaitu melaspas dan mendem pedagingan.

\subsection{Identifikasi Kasus}

Untuk mengetahui dan sekaligus sebagai pembanding antara pendapat para sumber dengan kenyataan yang sesuai dengan keadaan sebenarnya di lapangan, maka berikut ini akan dipaparkan identifikasi beberapa contoh kasus yang ada di lapangan.

\section{a. Gambaran Umum Kasus}

Beberapa kasus yang dipilih merupakan kasus yang memiliki karakteristik yang berbedabeda satu sama lainnya, baik dari segi fungsi, tata letak, dan bentuk pelinggih. Perbedaanperbedaan tersebut disebabkan karena didalam pemilihan lokasinya dipilih secara acak dibeberapa daerah yang kemungkinan memiliki kebudayaan yang berbeda-beda antara daerah yang satu dengan daerah yang lainnya.

\section{b. Klasifikasi Kasus}

Berikut ini merupakan beberapa kasus yang sudah didapatkan 
1. Sanggah keluarga bapak Putu Sulendra. yang berlokasi di Jl. Hos Cokroaminoto No. 70 Denpasar Utara.

2. Sanggah keluarga I Ketut Sarna yang berlokasi di Banjar Seseh, Desa Singapadu, kecamatan Sukawati Kab. Gianyar.

3. Sanggah keluarga Made Lopio yang berlokasi di Banjar Kacagan, Desa Ketewel, Kecamatan Sukawati Kab. Gianyar.

Tabel 01. Kesimpulan fungsi pelinggih gedong saren

\begin{tabular}{|c|c|c|c|c|c|c|}
\hline \multirow{2}{*}{ | } & \multirow{2}{*}{ BATASAN } & \multirow{2}{*}{ Fungsi Pelinggih Gedong Saren } & \multicolumn{3}{|c|}{ Sampel } & \multirow[t]{2}{*}{ Persentase } \\
\hline & & & 1 & 2 & 3 & \\
\hline $\begin{array}{l}\mathrm{F} \\
\mathrm{u} \\
\mathrm{n}\end{array}$ & Pelinggih & $\begin{array}{l}\text { Sebagai tempat pemujaan Ida } \\
\text { Betara Rambut Sedana }\end{array}$ & $X$ & $\mathrm{X}$ & $X$ & $100 \%$ \\
\hline \multirow[t]{2}{*}{$\begin{array}{l}g \\
s\end{array}$} & $\begin{array}{l}\text { Gedong } \\
\text { Saren }\end{array}$ & Sebagai pemujaan roh leluhur & & & & $0 \%$ \\
\hline & & Sebagai Pertiwi & & & & $0 \%$ \\
\hline
\end{tabular}

Tabel 02. Kesimpulan tata letak pelinggih gedong saren

\begin{tabular}{|c|c|c|c|c|c|c|}
\hline \multirow{2}{*}{ II } & \multirow{2}{*}{ BATASAN } & \multirow{2}{*}{ Tata Letak } & \multicolumn{3}{|c|}{ Sampel } & \multirow{2}{*}{ Persentase } \\
\hline & & & 1 & 2 & 3 & \\
\hline $\begin{array}{l}\mathrm{T} \\
\mathrm{A} \\
\mathrm{T}\end{array}$ & \multirow{3}{*}{$\begin{array}{l}\text { Posisi pelinggih } \\
\text { gedong saren } \\
\text { pada pemerajan } \\
\text { / pura }\end{array}$} & $\begin{array}{l}\text { Di sebelah utara } \\
\text { menghadap ke selatan }\end{array}$ & & & & $0 \%$ \\
\hline L & & $\begin{array}{l}\text { Di sebelah timur } \\
\text { menghadap ke barat }\end{array}$ & $X$ & $x$ & $x$ & $100 \%$ \\
\hline$A$ & & $\begin{array}{l}\text { Di depan pelinggih } \\
\text { pertiwi menghadap ke } \\
\text { barat }\end{array}$ & & & & $0 \%$ \\
\hline
\end{tabular}

Dari semua sample yang diambil, ternyata sebagian besar yaitu $100 \%$ posisi pelinggih gedong saren berada di sebelah timur menghadap ke barat 
Tabel 03. Kesimpulan konstruksi pelinggih gedong saren

\begin{tabular}{|c|c|c|c|c|c|c|}
\hline \multirow{2}{*}{ III } & \multirow[b]{2}{*}{ Batasan } & \multirow[b]{2}{*}{ Bahan yang dipakai } & \multicolumn{3}{|c|}{ Sampel } & \multirow[b]{2}{*}{ Persentase } \\
\hline & & & 1 & 2 & 3 & \\
\hline \multirow{9}{*}{$\begin{array}{l}\mathrm{K} \\
\mathrm{O} \\
\mathrm{N} \\
\mathrm{S} \\
\mathrm{T} \\
\mathrm{R} \\
\mathrm{U} \\
\mathrm{K} \\
\mathrm{S} \\
\mathrm{I}\end{array}$} & \multirow{3}{*}{ Atap } & ljuk & $\mathrm{x}$ & & & $35 \%$ \\
\hline & & Beton & & & $x$ & $35 \%$ \\
\hline & & Bahan lain & & $x$ & & $35 \%$ \\
\hline & \multirow{3}{*}{ Pengawak } & Batu bata & & $x$ & $x$ & $60 \%$ \\
\hline & & Paras & $x$ & $x$ & $x$ & $100 \%$ \\
\hline & & Plesteran & & & & $0 \%$ \\
\hline & \multirow{3}{*}{ Bebaturan } & Batu bata & & $x$ & $x$ & $60 \%$ \\
\hline & & Paras & $x$ & $x$ & $x$ & $100 \%$ \\
\hline & & \begin{tabular}{|l|} 
Plesteran \\
\end{tabular} & & & & $0 \%$ \\
\hline
\end{tabular}

Tabel 04. Kesimpulan ragam hias pelinggih gedong saren

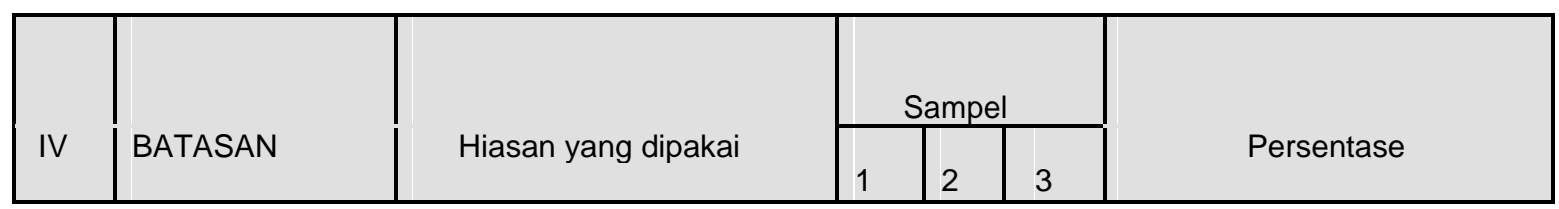

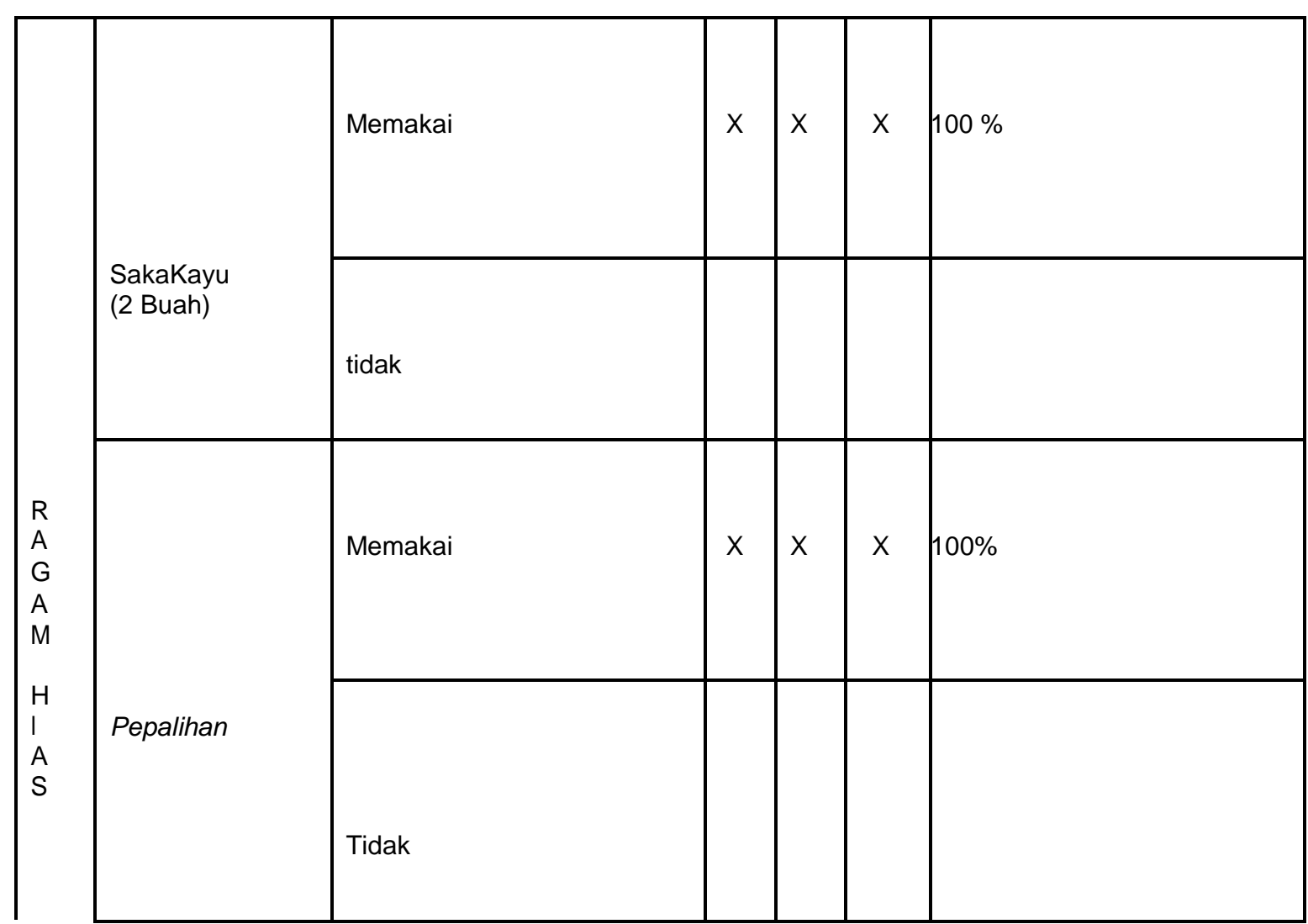




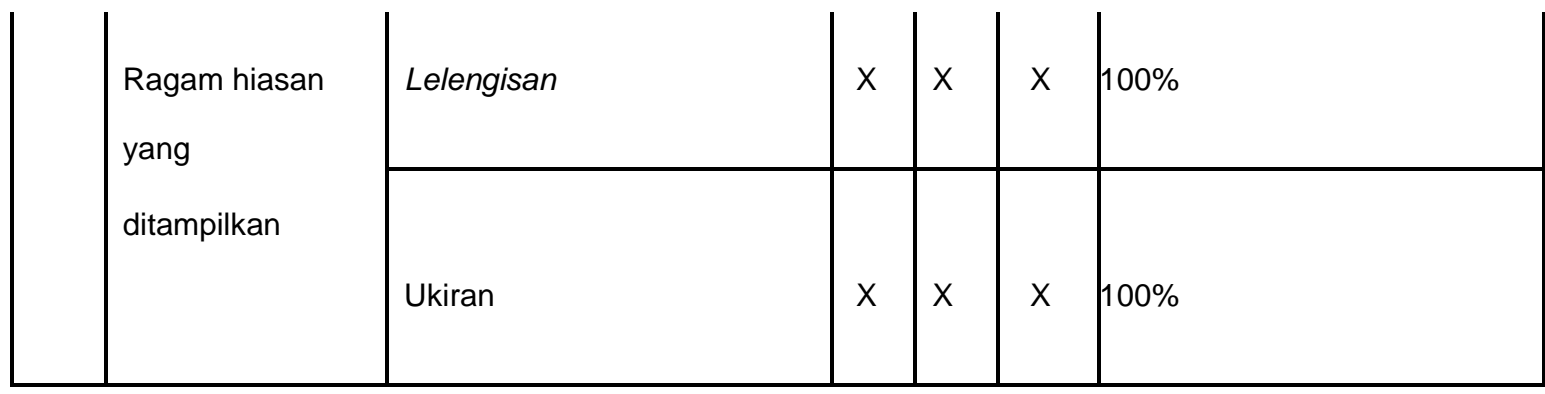

Tabel 05. Kesimpulan ritual pembangunan pelinggih gedong saren

\begin{tabular}{|c|c|c|c|c|c|c|}
\hline \multirow[b]{2}{*}{ VI } & & & & $\mathrm{mp}$ & & 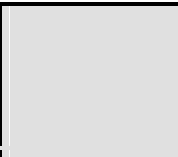 \\
\hline & BATASAN & Tata Letak & 1 & 2 & 3 & Persentase \\
\hline \multirow{6}{*}{$\begin{array}{l}R \\
\text { I } \\
T \\
U \\
A \\
L\end{array}$} & \multirow{3}{*}{$\begin{array}{l}\text { Upacara } \\
\text { pendirian }\end{array}$} & Membuat Gegulak & $\mathrm{X}$ & $\mathrm{x}$ & $X$ & $100 \%$ \\
\hline & & Nyukat & $X$ & $\mathrm{X}$ & $x$ & $100 \%$ \\
\hline & & Ngeruak \& Nasarin & $x$ & $x$ & $x$ & $100 \%$ \\
\hline & \multirow{3}{*}{ gedong saren } & Memakuh & $\mathrm{X}$ & $\mathrm{X}$ & $X$ & $100 \%$ \\
\hline & & Melaspas & $x$ & $\mathrm{X}$ & $x$ & $100 \%$ \\
\hline & & Mendem pedagingan & $x$ & $X$ & $x$ & $100 \%$ \\
\hline
\end{tabular}




\subsection{Tata Letak dan Tata Bangunan}

Berikut ini merupakan table hasil wawancara kami dengan beberapa sumber

Tabel 06. Kesimpulan fungsi pelinggih gedong saren

\begin{tabular}{|c|c|c|c|c|c|c|c|c|}
\hline \multirow{2}{*}{ । } & \multirow{2}{*}{ BATASAN } & \multirow{2}{*}{$\begin{array}{l}\text { Fungsi Pelinggih Gedong } \\
\text { Saren }\end{array}$} & \multicolumn{5}{|c|}{ Nara Sumber } & \multirow{2}{*}{ Persentase } \\
\hline & & & 1 & 2 & 3 & 4 & 5 & \\
\hline $\mathrm{F}$ & \multirow{3}{*}{$\begin{array}{l}\text { Pelinggih } \\
\text { Gedong } \\
\text { Saren }\end{array}$} & $\begin{array}{l}\text { Sebagai tempat pemujaan Ida } \\
\text { Betara Rambut Sedana }\end{array}$ & $X$ & & $x$ & $\mathrm{X}$ & & $60 \%$ \\
\hline$g$ & & $\begin{array}{l}\text { Sebagai pemujaan roh } \\
\text { leluhur }\end{array}$ & & $X$ & & & & $20 \%$ \\
\hline & & Sebagai Pertiwi & & & & & $x$ & $20 \%$ \\
\hline
\end{tabular}

Tabel 07. Kesimpulan tata letak pelinggih gedong saren

\begin{tabular}{|c|c|c|c|c|c|c|c|c|}
\hline \multirow{2}{*}{ I } & \multirow{2}{*}{ BATASAN } & \multirow{2}{*}{$\begin{array}{l}\text { Posisi Pelinggih Gedong } \\
\text { Saren }\end{array}$} & \multicolumn{5}{|c|}{ Nara Sumber } & \multirow{2}{*}{ Persentase } \\
\hline & & & 1 & 2 & 3 & 4 & 5 & \\
\hline $\mathrm{T}$ & Posisi & $\begin{array}{l}\text { Di sebelah utara menghadap } \\
\text { ke selatan }\end{array}$ & & & & & $x$ & $20 \%$ \\
\hline A & $\begin{array}{l}\text { pelinggih } \\
\text { Gedong } \\
\text { Saren pada } \\
\text { Merajan }\end{array}$ & $\begin{array}{l}\text { Di sebelah timur menghadap } \\
\text { ke barat }\end{array}$ & $\mathrm{x}$ & & $\gamma$ & $x$ & & $60 \%$ \\
\hline $\begin{array}{l}\mathrm{T} \\
\mathrm{A} \\
\mathrm{K}\end{array}$ & atau Pura & $\begin{array}{l}\text { Di sebelah selatan } \\
\text { menghadap ke barat }\end{array}$ & & $x$ & & & & $20 \%$ \\
\hline
\end{tabular}

Tabel 08. Kesimpulan tata bangunan pelinggih gedong saren

\begin{tabular}{|c|c|c|c|c|c|c|c|c|}
\hline \multirow[b]{2}{*}{1} & \multirow[b]{2}{*}{ BATASAN } & \multirow{2}{*}{$\begin{array}{l}\text { Fungsi Pelinggih Gedong } \\
\text { Saren } \\
\end{array}$} & \multicolumn{5}{|c|}{ Nara Sumber } & \multirow[b]{2}{*}{ Persentase } \\
\hline & & & 1 & 2 & 3 & 4 & 5 & \\
\hline$T$ & & & & & & & & \\
\hline $\begin{array}{l}\mathrm{A} \\
\mathrm{T}\end{array}$ & & Sari / Rongan ( Kepala ) & $x$ & $x$ & $x$ & $x$ & $x$ & $100 \%$ \\
\hline
\end{tabular}




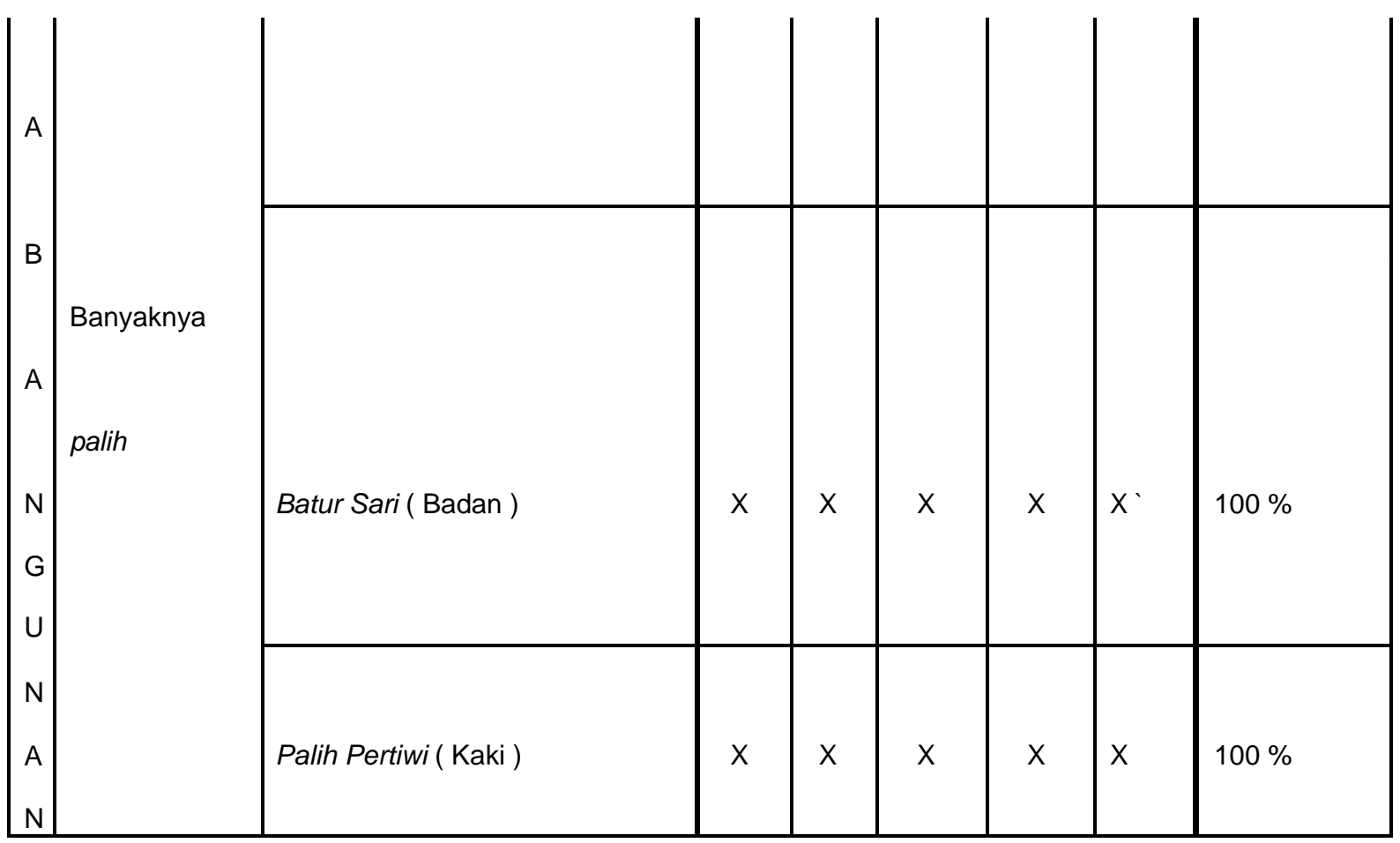

\section{Kesimpulan}

Berikut ini merupakan beberapa hal pokok yang dapat kami simpulkan mengenai pelinggih gedong saren yaitu

1. Fungsi pelinggih gedong saren (dari pendapat beberapa narasumber), sebagian besar menyebutkan bahwa fungsi dari pelinggih gedong saren adalah sebagai tempat pemujaan Ida betara rambut sedana. Jadi dapat disimpulkan bahwa fungsi pelinggih gedong saren adalah memang sebagai tempat pemujaan terhadap Ida betara rambut sedana, dimana bagi masyarakat Bali khususnya sangat dipuja karena sebagai dewa rejeki. Pada rahina buda cemeng klawu disebut sebagai piodalan Ida betara rambut sedana, dimana masyarakat Bali selalu menghaturkan sesajen sebagai ungkapan rasa syukur atas rejeki yang telah diterima.

2. Tata letak pelinggih gedong saren (dari beberapa sumber dan beberapa kasus yang sudah kami dapatkan), ternyata tata letak pelinggih gedong saren lebih dominan letaknya di sebelah timur menghadap ke barat. Jadi tata letak pelinggih gedong saren yang berfungsi untuk memuja Ida ratu rambut sedana letaknya di sebelah timur berjejer dengan pelinggih-pelinggih yang ada di timur menghadap ke barat. Sedangkan pelinggih gedong saren yang letaknya di sebelah utara yang mengarah ke selatan adalah berfungsi sebagai pertiwi.

Dari uraian pada bab-bab sebelumnya dapat ditarik kesimpulan sebagai berikut:

a. Keberadaan pelinggih gedong saren erat kaitannya dengan pemahaman tentang dimana kita mendapatkan rejeki untuk bisa melangsungkan hidup. Dimana pelinggih gedong saren merupakan suatu simbolis penghormatan terhadap lda betara rambut sedana terhadap masyarakat Bali.

b. Fungsi pelinggih gedong saren adalah sebagai tempat pemujaan terhadap Ida betara rambut sedana. Sebagai wujud rasa syukur masyarakat Bali maka setiap pemerajan 
gede dan pura-pura tertentu didirikan pelinggih gedong saren atau pelinggih Ida betara rambut sedana.

c. Keunikan pelinggih gedong saren adalah terdapatnya 2 (dua) buah saka di depan pelinggih, dan bentuk rongan yang tertutup. Pelinggih gedong saren berfungsi sebagai bentuk persembahan kepada dewa / bhatara.

d. Tata letak pelinggih gedong saren berada di sebelah timur berjejer dengan pelinggih yang ada di sebelah timur menghadap ke barat.

e. Secara keseluruhan tampak dari pelinggih gedong saren dengan pelinggih-pelinggih yang lain yaitu menggunakan 3 (tiga) palih yaitu: palih pertiwi; palih batur sari dan palih rongan atau sari

f. Sesuai dengan asal kata Saren yaitu mesare, pesarenan yang artinya tempat ber stana atau istirahat para dewa / bhatara.

g. Pelinggih gedong saren dapat kita jumpai pada sanggah-sanggah gede dan pada purapura tertentu.

h. Rancangan pelinggih gedong saren memakai sikut-sikut atau ukuran-ukuran tradisional Bali.

i. Dalam pendirian pelinggih gedong saren harus mengikuti proses dan upacara yang sesuai dengan aturan arsitektur tradisional Bali.

\section{SARAN}

Keberadaan pelinggih gedong saren harus tetap kita pertahankan, karena pelinggih gedong saren merupakan wujud syukur kita kehadapan Ida Sang Hyang Widhi Wasa atas segala karunia-Nya serta merupakan warisan dari pendahulu kita yang di dalamnya mengandung nilai-nilai filosofis dan sejarah yang harus selalu diingat dan kita tanamkan kepada generasi orang-orang atau masyarakat Hindu Bali selanjutnya

\section{DAFTAR PUSTAKA}

Aryana, I.B. Putra, M. SS., (2007) Indik Karang Panes (Menyingkap Hunian Manusia Yang Mendatangkan Bahaya), Denpasar: Bali Aga.

Artadi, I Ketut, SH., SU, (2011), Kebudayaan Spiritualitas, Nilai Makna dan Martabat Kebudayaan. (Dimensi Tubuh Akal Roh dan Jiwa), Denpasar: Pustaka Bali Post.

Bonta, J P, 1979, Architecture and its interpretation, Rizzoli International Publications, INC.

Bidja, I Made, 2000, Asta Kosala-Kosali, Asta Bumi, Denpasar: BP.

Etlin, Richard A, 1994, Symbolic Space, London: The University of Chicago Press, Ltd.

Gelebet, I Nyoman, Ir, Pokok-pokok Pengarahan arsitektur Tradisional Bali. Gelebet, I Nyoman, Ir., 1981/1982, Arsitektur Tradisional Daerah Bali, Departemen Pendidikan dan Kebudayaan, Proyek Inventarisasi dan Dokumentasi.

Madrasuta, Ngakan Made, Editor, (2010), Spiritualitas Hindu, Untuk Kehidupan Modern, Denpasar: PT. Percetakan Penebar Swadaya.

Paketan, Ida Bagus Anom, (2005), Membangun Karang Paumahan. 


\section{LAMPIRAN}
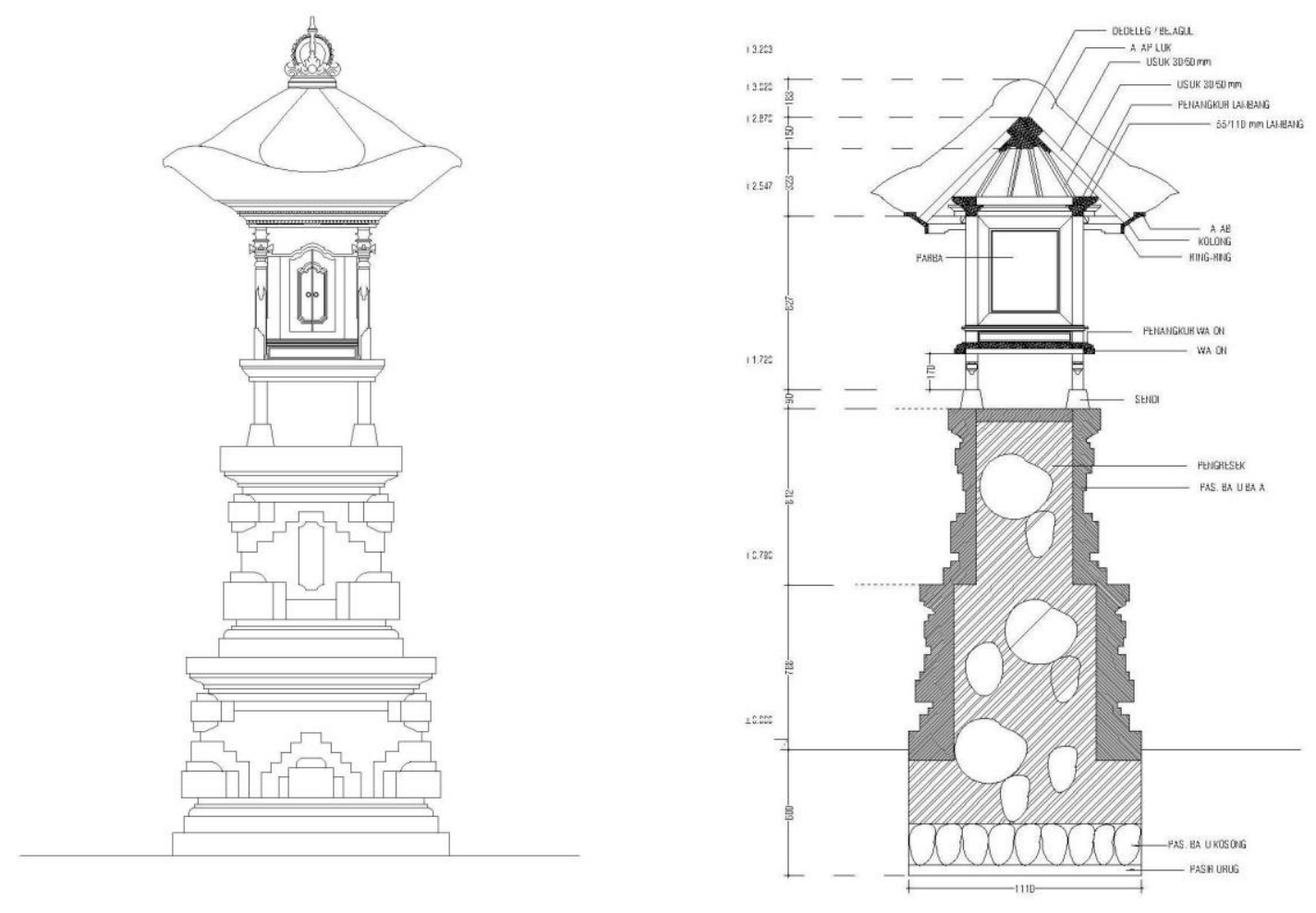

Potongan Pelinggih Gedong Saren
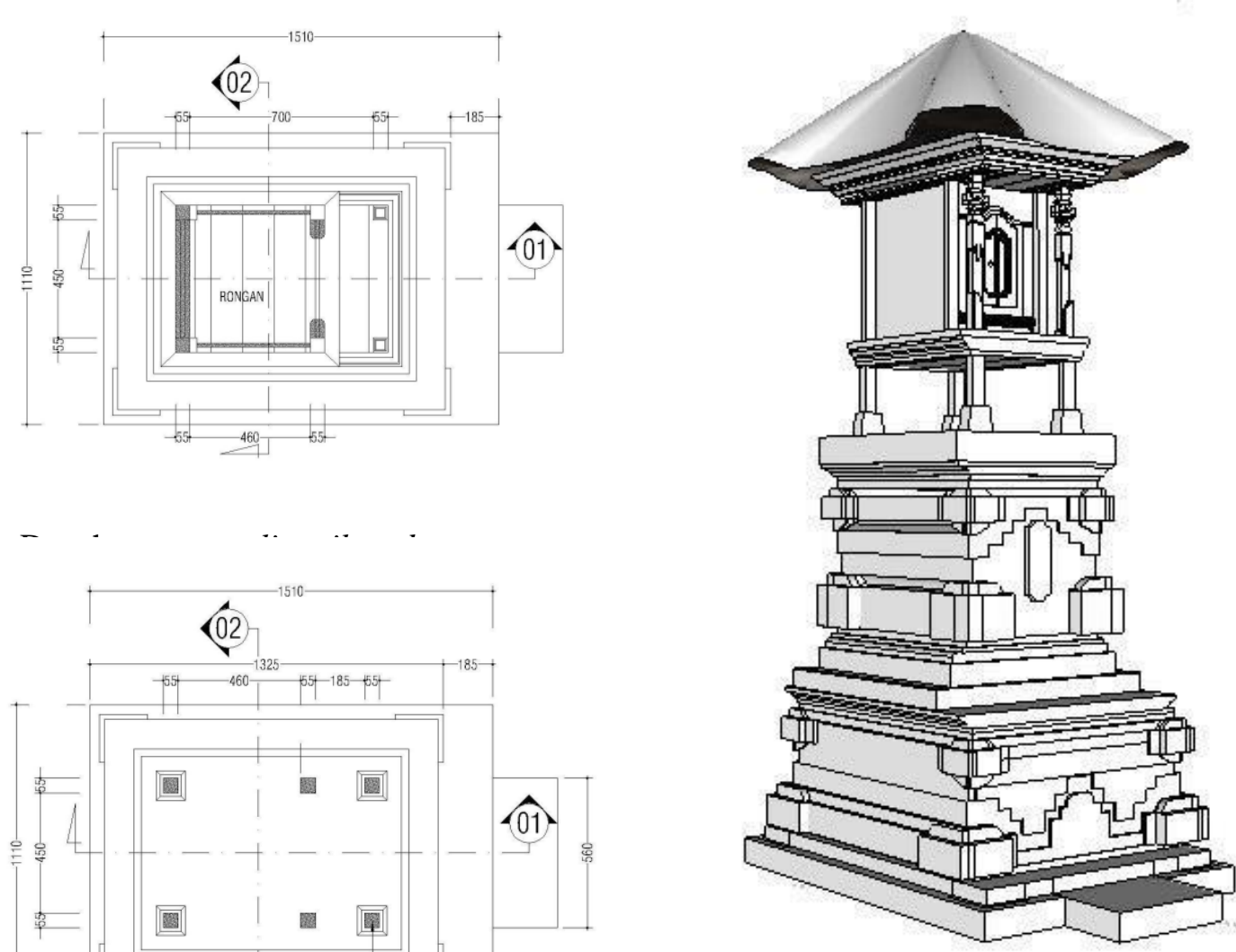